\title{
Genç Üniversite Öğrencilerinin Girişimcilik Niyeti üzerinde Planlı Davranış Teorisi ile birlikte Fırsatları Görme ve Teşvik Desteğinin Etkisi
}

\section{The Impact of Seeing Opportunities and Incentive Support with the Theory of Planned Behaviour on Entrepreneurial Intention of Young University Students}

\author{
Arzu Tuygun Toklu*a \\ ${ }^{\text {a} D r . ~ O ̈ g ̆ r e t i m ~ U ̈ y e s i, ~ R e c e p ~ T a y y i p ~ E r d o g ̆ a n ~ U ̈ n i v e r s i t e s i, ~ F ı n d ı k l ı ~ U y g u l a m a l ı ~ B i l i m l e r ~ Y u ̈ k s e k o k u l u, ~ R i z e / T u ̈ r k i y e . ~}$ \\ ORCID: 0000-0003-2041-0747
}

\section{MAKALE BILGIISI}

Makale Geçmişi:

Başvuru tarihi: 01 Eylül 2019

Düzeltme tarihi: 29 Aralık 2019

Kabul tarihi: 10 Ocak 2020

\section{Anahtar Kelimeler:}

Girişimcilik Niyeti

Planlı Davranış Teorisi

Fırsatları Görme

Teşvik Desteği

\section{ÖZ}

$\mathrm{Bu}$ çalışmanın amacı üniversitede öğrenim gören bireylere sağlanan teşvik desteğinin girişimcilik niyetine etkisini araştırmaktır. Bu amaçla yapılan araştırma ile finansal destek yanında, firsatları görme, girişimcilik davranışına yönelik kişisel tutum, algılanan davranışsal kontrol ve sübjektif normun bireylerin girişimcilik niyetine etkisi incelenmektedir. Araştırmanın verileri Uygulamalı Bilimler Yüksekokulunda henüz girişimcilik dersi almamış ikinci sınıf öğrencileri arasından kolayda örnekleme yöntemiyle elde edilmiştir. Web tabanlı anket yöntemi ile toplanan veriler SPSS v23 ve SmartPLS YEM kullanılarak analiz edilmiştir. Araştırmanın bulgularına göre, finansal destekle birlikte girişimcilik davranışına yönelik kişisel tutum ve algılanan davranışsal kontrol, girişimcilik niyeti üzerinde etkili iken, firsatları görme ve sübjektif norm etkili bulunamamıştır. Eğitim ve ögretimle geliştirilebilen girişimcilik için üniversitelerde girişimcilik bakış açısına sahip olunmasının ülkenin kalkınmasında ilave değer oluşturacağı düşünülmektedir.

\section{A R T I CLE INFO}

\section{Article history:}

Received 01 September 2019

Received in revised form 29 December 2019

Accepted 10 December 2020

\section{Keywords:}

Entrepreneurial Intention

Theory of Planned Behaviour

Seeing Opportunities

Incentive Support

\section{A B S T R A C T}

The aim of the study is to investigate the effect of incentive support provided to individuals who are studying in university. In addition to financial support, the research focuses on the effects of seeing opportunities, personal attitude towards entrepreneurial behavior, perceived behavioral control, and subjective norm on individuals' entrepreneurial intention. The data were selected by using convenience sampling method among the second year students who were not taken the entrepreneurship course in the School of Applied Sciences. The data collected by using web-based survey were analyzed using SPSS v23 and SmartPLS SEM. According to the findings, financial opportunities with personal attitude towards entrepreneurship behavior and perceived behavioral control have effects, while there are no effects with seeing opportunities and subjective norm on entrepreneurial intention. Having entrepreneurship point of views in universities for entrepreneurship that can be improved through education and training is considered to be an added value in the development of the country.

\section{Giriş}

Girişimcilik temel olarak değişim fikriyle çerçevelenmiş bir kavramdır (Henley vd., 2017). Girişimci, bir eylem başlatarak mevcut olanı geliştiren ve yenilikler yaratan kişidir (Wennekers vd., 2002). Girişimciler kendilerini diğerlerinden ayıran ve farklı kılan benzersiz değerlere, tutumlara ve ihtiyaçlara sahip bireylerdir (Cunningham ve
Lischeron, 1991). Girişimciliği toplumsal düzeyde etkilemek için demografik yapıların ve kültürün bireylerde sahip olunması gereken koşulları bir araya getirmesi gerekmektedir (Wennekers vd., 2002). Stamboulis ve Barlas'a (2014) göre girişimcilik, çeşitli sosyal, kültürel, çevresel, demografik ve ekonomik faktörlerden etkilenen çok yönlü bir çabadır ve burada girişimciliği etkileyen faktörler ve engeller olmak üzere iki sınıf tanımlanabilir. 
Gaddam (2007) etkileyen faktörler kapsamında ekonomik, psikolojik, sosyal, çevresel, demografik ve kültürel olmak üzere altı ana faktör grubunun başarılı bir girişimcilik arayışına yol açtığını belirtmektedir. Armstrong ve Hird (2009) ve Marques vd. (2012) psikolojik özellikler ile girişimci yönelimi arasındaki korelasyonun yaygın olduğunu ifade etmektedir. Engeller ise bireysel, örgütsel ve çevresel olmak üzere üç kategoriye ayrılır. Aile ve eğitim bireysel engeller sınıfinda; finans, fiziksel kaynaklar ve pazarlama örgütsel engeller sınıfında; sosyo kültürel faktörler ile kurallar ve düzenlemeler çevresel engeller arasındadır.

Farklı ülkelerde yapılan birçok araştırma girişimcilik faaliyetlerinin seviyesi ile ekonomik kalkınma arasındaki bağlantının güçlü olduğunu göstermiştir (Chaudhary, 2017). Girişimciliğin gelişmekte olan ülkeler için bir büyüme lokomotifi olduğu kabul edildiğinden, bu tür araştırmaların radikal bir şekilde arttığı günümüzde ilginin de asla kaybolmayacağı düşünülebilir. Buradan hareketle, 2050 yılına kadar dünyanın en büyük ekonomisi olacağı öngörülen Hindistan ekonomisinin de ülkedeki girişimci kültürü teşvik etme ve cesaretlendirme çabalarını artırdığı belirtilmektedir (Chaudhary, 2017).

Girişimciliğin ülkelerin gelişimine olan katkılarının belirgin olarak ortaya çıkmasıyla birlikte akademik olarak incelenmeye başladığı görülmektedir. Abou-Warda'nın (2015) belirttiğine göre, girişimcilik 1940'ların sonlarından bu yana ABD'nde üniversitelerde çalışılmaktadır. İngiltere'de, Yüksek Öğrenim kurumları programlar tasarlanırken girişimciliğin kullanılması teşvik edilmiştir (National Committee of Inquiry into Higher Education, 1997, s. 201) ve 2000 y1lında ise işletme ve girişimcilik gelişimi, Britanya Üniversiteleri için dört stratejik hedeften biri olarak sıralanmıştır (Universities UK, 2000). Kore'de sadece birkaç kolej, ülkedeki girişimci kültür eksikliğinden dolayı bir işletme alanı olarak girişimciliği geliştirmişken, Japonya Ocak 2001'de ilk kez bir çalışma alanı olarak girişimciliği başlatmayı planladığını resmen açıklamıştır (Lee vd., 2005). Buradan üniversitelerin daha girişimci olmaya teşvik edildiği gözlenmektedir (Mowery ve Shane, 2002). Bu şekilde işletme okullarının bilgiye dayalı girişimcilik için en yüksek potansiyele sahip kurumlar haline geldiği belirtilirken, üniversiteler ve bölümleri arasındaki kültürel farklılıkların girişimci yönelimini etkileyen faktörler arasında olduğu saptanmıştır (Lee vd., 2005). Üniversitelerde girişimcilik çalışmalarının kapsamı, her ülkenin kendine özgü kültürel bağlamına göre de farklılık göstermektedir (Lee ve Peterson, 2000). Diğer taraftan, girişimcilik niyetinin oluşturulmasında ve geliştirilmesinde sadece girişimcilik eğitiminin yeterli olmadığı, genetik faktörlerle birlikte bireysel ve çevresel faktörlerin de önemli olduğu belirtilmektedir (Kerse vd., 2017).

$\mathrm{Bu}$ çalışmada üniversitede öğrenim gören bireylere sağlanacak finansal destek yanında, firsatları görme ve girişimcilik davranışına yönelik kişisel tutum, algılanan davranışsal kontrol ile sübjektif norm gibi kişisel özelliklerinin girişimcilik niyetine etkisi araştırılmaktadır. Bu kişisel özelliklerin ortaya çıkarılmasında Ajzen'in (1991) "Planlı Davranış Modeli” göz önünde bulundurulmuştur.

Üniversiteler hizmet üreten kamu ya da özel sektör kuruluşlarıdır. Ülkelerin geleceği için yetişmiş insan kaynağının geliştirilmesinde önemli bir boşluğu doldurması beklenmektedir. Türkiye'nin yükseköğrenimde son yıllarda yaptığı atılımlarda fiziksel imkânların sağlandığı görülmekle birlikte niteliğin sorgulanmaya başladığı izlenmektedir. Üniversitelerin iş dünyasının taleplerine yeterince karşılık verememeleri yapılan büyük yatırımların tekrar gözden geçirilmesine neden olmaktadır. Burada üniversitelerin girişimci bireyler yetişmesinin de önünün açılması için girişimcilik bağlamında mevcut durumun sorgulanmasının gerektiği açıktır. Bu çalışma öğrencilerin girişimcilik niyeti ve bunu etkileyen belirli öncülleri değerlendirmesi açısından anlamlıdır. Girişimcilik konusunun akademik düzeyde daha fazla incelenmesinin farkındalığın artmasına ve ülkenin kalkınmasına aracılık edeceği düşünülmektedir.

\section{Teorik Temel ve Hipotez Oluşturma}

Girişimciler firsatları görüp ekonomik gelişmeyi ivmelendirdiklerinden iddia sahibi ve yenilikçidirler. Girişimcilik varlık yaratma ve ekonomik kalkınmaya odaklanma olarak görülmektedir. Bir girişimin kurucusunun kişisel eğilimlerine uygun bir yöne doğru ilerlemeye çalıştığı belirtilmektedir (Lumpkin ve Lichtenstein, 2005). Burada girişimci yönelimi, ilk önce yeni iş fırsatları arayan bireyin bireysel yönelimi ve daha sonra bir işletme düzeyinde süreçler, uygulamalar ve karar alma faaliyetleri olarak çeşitli düzeylerde üzerinde çalışılması gereken bir kavramdır (Elenurm, 2012)

Schumpeter (1928), girişimcinin rolünü mevcut üretim sistemlerini dönüştüren yaratıcı yıkıma bağlarken, Kirzner (1978) girişimcilik teorisinde, girişimcinin pazarda kullanılmayan firsatları keşfetmedeki rolü nedeniyle pazarda itici bir güç olduğu ve girişimcilerin rekabetçi davranışlarının pazarda dengeyi sağlama faaliyeti gösterdiğini belirtmektedir. Knight (1921) ise risk ve belirsizlik arasında bir ayrım yapmıştır. Yenilikçi girişimciler, genellikle farklı iş geliştirme sonuçlarının bilinme olasılıklarının belirsizliği ile karşı karşıya kalırlar. Yerleşik işletmelerin en iyi uygulamalarını kopyalayan girişimciler, işletme ortamı köklü olarak değişmediği sürece işletmelerini geliştirme konusundaki belirsizliği sınırlandırma şansına sahiptir (Elenurm, 2012).

$\mathrm{Bu}$ bilgiler temelinde girişimcilik niyeti, firsatları tanıma, bilgi arama, kaynakları bulma ve iş stratejileri oluşturmayı içeren girişimcilik faaliyetine öncülük eden bir süreç olarak tanımlanmaktadır (Krueger ve Carsrud, 1993). Girişimcilik niyetini açıklamaya çalışan çeşitli modeller olmasına rağmen teoriye dayalı çalışmalarda en yaygın kullanılanlardan biri Planlı Davranış Teorisidir (the theory of planned behaviour) (Ajzen, 1991). Bu teori özünde girişimcilik niyetinin üç faktöre dayandığını ifade eder (Krueger vd., 2000). Birincisi, algılanan arzu edilebilirliktir, yani bir bireyin girişimciliğe karşı sahip olduğu tutum veya çekim derecesidir. İkincisi, algilanan bir fizibilitedir; bu, bireyin kendi kendine yeterliliği ölçüsü, kendi kendini algılayan bir girişimcilik kapasitesidir. Üçüncüsü ise sosyal normlar, algılanan normatif sosyal baskı düzeyi ve bu tür bir davranışı benimseme inancıdır. Bu kavramsal düzende girişimcilik faaliyeti bu faktörlerin niyet üzerindeki etkilerinden tahmin edilebilir.

Yukarıda belirtildiği gibi girişimcilik, çeşitli sosyal, kültürel, çevresel, demografik ve ekonomik faktörlerden etkilenen çok yönlü bir çabadır. Burada demografik özellikler veya kişilik özellikleri gibi bireysel öncül faktörler ve tamamen 
durumsal faktörler etkilidir (Ajzen, 2011; Krueger vd., 2000).

\subsection{Girişimcilik Davranışına Yönelik Kişisel Tutum}

Ajzen'in (1991) Planlı Davranış Teorisi kişisel tutumu bir davranışın olumlu ya da olumsuz değerlendirme derecesi olarak tanımlar. Bu da kişisel tutumu girişimcilik niyetinin belirleyicilerinden birisi yapar. Girişimcilik niyetinin nasıl oluştuğunu açıklamada değerler ve motivasyonlar bir işlev üstlenebilir (Fayolle vd., 2014). Kişisel değerler girişimcilikte önemli bir göreve sahiptir (Hemingway, 2005). Farklı motivasyonların değişen düzeylerde kişisel tutuma etki edebileceği ve onun da girişimcilik niyetinde söz sahibi olabileceği belirtilmektedir (Solesvik, 2013). Bu temelde araştırmanın hipotezi şu şekilde oluşturulabilir.

H1: Girişimcilik davranışına yönelik kişisel tutum girişimcilik niyetini etkiler.

\subsection{Algılanan Davranışsal Kontrol}

Ajzen'in (1991) Planlı Davranış Teorisi algılanan davranışsal kontrolü bir davranışı yerine getirmenin algılanan kolaylığı veya zorluğu olarak tanımlar. Bu girişimci bir davranışı gerçekleştirmede birey tarafindan algılanan kişisel kolaylık veya zorluğa yönelik bir inançtır (Maes vd., 2014). Yaratıc1lık ve risk alma olarak da ifade edilebilen davranışsal kontrol girişimci davranışını tahmin etmede kullanılan modellerin temelinde vardır (Krueger vd., 2000). Bireyin mevcut çevresi, kaynakları ve oluşan süreçler girişimcilik niyeti üzerinde önemli bir etkiye sahiptir (Solesvik vd., 2014). $\mathrm{Bu}$ temelde araştırmanın hipotezi şu şekilde oluşturulabilir.

H2. Algılanan davranışsal kontrol girişimcilik niyetini etkiler.

\subsection{Sübjektif Norm}

Ajzen'in (1991) Planlı Davranış Teorisi sübjektif normu bir davranışın gerçekleştirilmesi ya da gerçekleştirilmemesindeki sosyal baskıyı ifade eder. Yani belirli öneme sahip bireylerin veya grupların yine belirli olan bir davranışı destekleme ya da desteklememe ihtimalidir. Benzer şekilde, belirli bir davranışın yapılmasında sosyal baskı ya da diğerlerinin bakışını ifade eder (Díaz-García ve Jiménez-Moreno, 2010; Liñán ve Chen, 2009). Bir girişime yönelen öğrenciler rol modeli ya da mentor olan ailelerinin, arkadaşlarının veya önemli etkiye sahip diğer bireylerin fikirlerine değer verir (Krueger vd., 2000). Bu yakın insanlardan alınan bir algılanan destektir. $\mathrm{Bu}$ temelde araştırmanın hipotezi şu şekilde oluşturulabilir.

H3: Sübjektif norm girişimcilik niyetini etkiler.

\subsection{Frrsatları Görme}

Literatür yetkinliklerin girişimciler için önemli olduğunu vurgulamaktadır. Yetkinlikler, bilgi, beceri ve tutumların birleşik ve bütünleşik bileşenleri olarak tanımlanır (Kyndt ve Baert, 2015) ve bazı yazarlar yetkinliklerin deneyim, eğitim veya koçluk yoluyla değişken, öğrenilebilir ve ulaşılabilir olduğunu iddia eder (Volery vd., 2015). Başarıll girişimciler mevcut ve gelecekteki rakiplerini bildikleri gibi sürekli gelişen pazarda nasıl konumlandıklarını da bilirler. Gelişen pazarlar girişimcilerin dinamik olma, güncel kalma ve uygun konumlanması için özellikle önemlidir. Başarılı girişimciler pazardaki firsatları belirleme ve kullanma becerilerine sahiptirler (Gras ve Mendoza-Abarca, 2014). Mevcut yapisı ile pazarlar dinamik olduğundan her zaman firsatları ve tehditleri içerebilir. $\mathrm{Bu}$ firsatlar bir girişimin önünü açabilirken, tehditten kaçma da yeni firsatları beraberinde getirebilir.

H4: Fırsatları görme girişimcilik niyetini etkiler.

\subsection{Finansal Destek}

Doğrudan yardım ve destek programları girişimciliğin önündeki engellerin etkisini en aza indirirken bireylere daha iyi ekonomik firsatlar yaratır ve yerel ekonomik kalkınmayı destekler (Van Auken, 1999). T.C. Sanayi ve Teknoloji Bakanlığı bünyesinde faaliyet gösteren KOSGEB (2019) olarak anılan T.C. Küçük ve Orta Ölçekli İşletmeleri Geliştirme ve Destekleme İdaresi mevcut küçük ve orta boy işletmelere çeşitli destekler sunmasının yanında girişimcilere de nakdi ve gayri nakdi olmak üzere çeşitli destekler vermektedir. Son y1llarda sermayesini ve faaliyetlerini oldukça geliştirmesine rağmen halen sınırlı bütçeyle faaliyet gösteren KOSGEB'in hazırladığı destek paketleri ile kendi işini kurmak isteyen özellikle genç girişimcilere belirli dönemlerde önemli firsatlar sunduğu görülmektedir. $\mathrm{Bu}$ destekler hibe destekler, kuruluş aşamasındaki destekler, faizsiz geri ödemeli sabit yatırım destekleri, düşük faizli işletme kredileri şeklinde çeşitlendirilebilmektedir. Burada kamunun yaptığ 1 girişimciliği destekleyerek doğrudan istihdam sağlama kapasitesini düşürüp ekonominin özel sektör aracıllğı ile geliştirilmesine çaba göstermesidir. Ekonomiyi canlandırmak için teşvikler sunarak girişimcilerin girişimcilik niyetine olumlu yönde etki etmeyi hedeflemektedir. Buna göre araştırmanın hipotezi aşağıdaki şekilde kurgulanabilir.

\section{H5. Finansal destek girişimcilik niyetini etkiler.}

$\mathrm{Bu}$ teorik temele dayanarak Şekil 1'de gösterilen araştırmanın modeli oluşturulmuştur. Oluşturulan kavramsal modele göre algılanan kişisel tutum, algılanan davranışsal kontrol, sübjektif norm, firsatları görme ve finansal destek girişimcilik niyetini etkiler. Model aşağıdaki metodoloji yardımıyla test edilmiştir. 


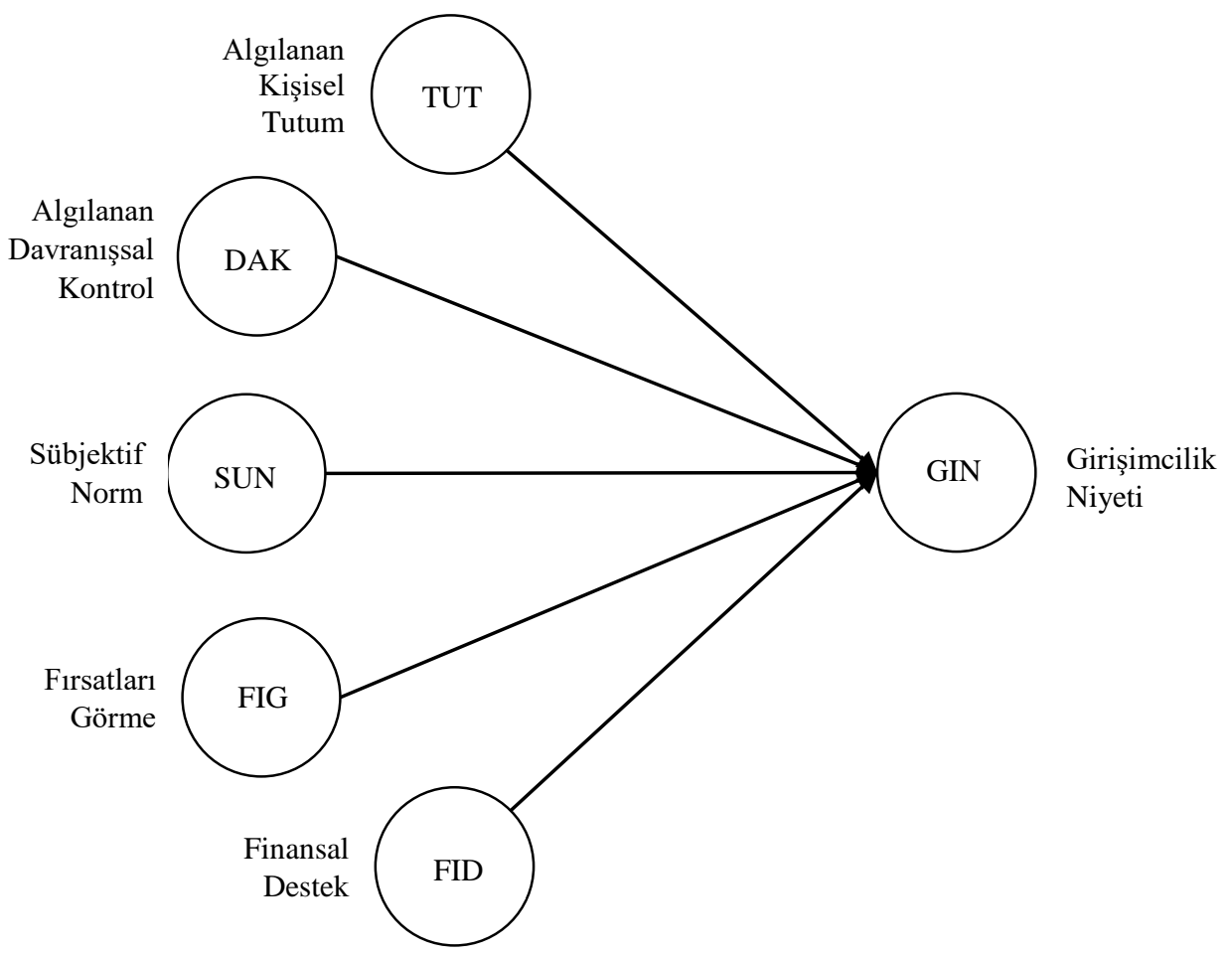

Şekil 1. Araştırma modeli

\section{Metodoloji}

Araştırmada kullanılan değişkenlerin ölçekleri için literatürden faydalanılmıştır. Davranışa yönelik kişisel tutum için Ajzen (1991) çalışması temelinde oluşturulan Toklu'nun (2018) da kullandığı ölçekten yararlanılmıştır. Sübjektif norm, algılanan davranışsal kontrol ve girişimcilik niyeti için ise Buli ve Yesuf (2015) ile Toklu (2018) tarafindan kullanılan ölçekler kullanılmıştır. Fırsatları görme ölçeği için Kyndt ve Baert (2015) tarafından kullanılan ölçekten yararlanılmıştır. Anket sorularının tasarımında "kesinlikle katılmıyorum" 1 ve "tamamen katılıyorum" 5 şeklinde kodlanan beşli Likert kullanılmıştır. Teşvik desteği için ölçek KOSGEB'in girişimciliğe sağladığı destekler göz önünde bulundurularak Toklu (2019) tarafindan geliştirilen ölçek kullanılmıştır. Beş maddeli teşvik desteği için sorularda "hiç önemli değil" 1 ve "çok önemli" 5 olacak şekilde beşli Likert kullanılmıştır.

Araştırmanın evreni henüz girişimcilik dersi almamış üniversite öğrencileridir. Burada girişimcilik dersi öncesi mevcut durum araştırırılarak daha sonra yapılacak boyutsal analiz (girişimcilik öncesi durum ve girişimcilik sonrası durum) için de bir veri seti oluşturulmaktadır. Bu amaçla çalışmanın verileri Recep Tayyip Erdoğan Üniversitesinin 4 yıllık Findıklı Uygulamalı Bilimler Yüksekokulunda öğrenim gören ikinci sınıf öğrencileri arasından kolayda örnekleme yöntemi kullanılarak anketle elde edilmiştir. 6 Mart 2019 tarihinde yapılan web tabanlı ankete 105 kişi katılmıştır. Bunlardan 6 tanesi eksik ya da hatalı olarak değerlendirildiğinden analiz dışı bırakılarak 99 anket ile analizler yapılmıştır. Bu verilerin analizinde küçük örneklem sayısı ile çalışabilen ve parametrik olmayan (Hair vd., 2014) SmartPLS Yapısal Eşitlik Modellemesi kullanılmıştır. Frekansların hesaplanmasında IBM SPSS v23 istatistik programından yararlanılmıştır.
Hair vd. (2014) bir PLS analizi için en küçük örnek sayısının "en az on katı kuralı" na uygun olması gerektiğini belirtmektedir (Toklu ve Ustaahmetoğlu, 2016). Bu 99 olan örneklem sayısının araştırma için yeterli bir sayı olduğunu teyit eder.

\section{Analiz Sonuçları}

Tablo 1 araştırmaya katılanların tanımlayıcı istatistikleri vermektedir.

Tablo 1. Katılımcıların tanımlayıcı istatistikler

\begin{tabular}{|c|c|c|c|}
\hline Demografik Özellikler & & Frekans & $\%$ \\
\hline \multirow{2}{*}{ Cinsiyet } & Kadın & 67 & 67,7 \\
\hline & Erkek & 32 & 32,3 \\
\hline \multirow[t]{2}{*}{ Yaş } & $<20$ & 29 & 29,3 \\
\hline & $20-30$ & 70 & 70,7 \\
\hline \multirow[t]{3}{*}{ İş Tecrübesi } & Tecrübesiz & 92 & 92,9 \\
\hline & $<3 \mathrm{y} 11$ & 5 & 5,1 \\
\hline & $\geq 3 \mathrm{y} 1 \mathrm{l}$ & 2 & 2,0 \\
\hline \multirow[t]{7}{*}{ Coğrafi Bölge } & Karadeniz & 45 & 45,4 \\
\hline & Marmara & 19 & 19,2 \\
\hline & Akdeniz & 13 & 13,1 \\
\hline & İç Anadolu & 8 & 8,1 \\
\hline & Ege & 7 & 7,1 \\
\hline & Güneydoğu Anadolu & 5 & 5,1 \\
\hline & Doğu Anadolu & 2 & 2,0 \\
\hline \multirow[t]{3}{*}{ Kardeş sayı1sı } & 1 & 7 & 7,1 \\
\hline & 2 & 25 & 25,3 \\
\hline & 3 ve daha fazla & 67 & 67,7 \\
\hline
\end{tabular}

Katılımciların \%67,7'si kadın ve \%32,3'̈̈ erkeklerden oluşmaktadır. \%29,3'ü 20 yaşından küçük iken \%70,7'si 20- 
30 yaş aralığındadır. \%92,9’u henüz bir iş deneyimine sahip değilken, \%5,1'i üç yıldan az, \%2'si üç ve üç yıldan fazla deneyime sahiptir. \%45,4'ü Karadeniz, \%19,2'si Marmara, \%13,1'i Akdeniz, \%8,1'i İç Anadolu, \%7,1'i Ege, \%5,1'i Güneydoğu Anadolu ve \%2'si de Doğu Anadolu bölgesindendir. \%7,1'i bir kardeşe, \%25,3'ü iki kardeşe ve $\% 67,7$ 'si de üç ve daha fazla kardeşe sahiptir.

\subsection{Verilerin Analizi}

Model analiz edilirken ölçüm modeli ve yapısal model incelenmektedir. Ölçüm modeli gözlenen ve gizil değişkenler arasındaki ilişkiyi, yapısal model de gizil değişkenler arasındaki ilişkiyi araştırır. Burada yapıların hem güvenilir hem de geçerli olması esastır.

\section{2. Ölçüm Modeli}

Yakınsak ve ayrıksak geçerlilikleri yapının geçerliliği kapsamında araştırılır. Madde güvenilirliği, kompozit güvenilirlik ve açıklanan ortalama varyans (AVE) yakınsak geçerlilik için kullanılır. Burada maddelerdeki yüklerin 0,70'in üzerinde bir değerde olması güvenilirliği arttırır (Hulland, 1999). Bu değerin altındaki maddelerin analizden çıkarılması gerekir. Cronbach'ın Alfa katsayısının 0,6'nın üzerinde olması kompozit güvenilirlik için yeterlidir (Hair vd., 2014). Kompozit güvenilirlikler de 0,7 olan eşik değerin üzerindedir. Yakınsak geçerliliğin teyit edilmesinde kullanılan AVE değerleri için eşik değer 0,50 ve üzeridir. Tüm değerler belirtilen eşik değerlerin üzerinde olduğundan modelin yakınsak geçerliliği teyit edilmiştir (Hair vd., 2014). Tablo 2 belirtilen değerleri vermektedir.

Tablo 2. Ölçüm modelinin değerlendirilmesi

\begin{tabular}{|c|c|c|c|c|c|c|}
\hline Gizil Değiş̧ken & Madde & Yükler & $\begin{array}{c}\text { Madde } \\
\text { Güvenilirliği }\end{array}$ & $\begin{array}{c}\text { Cronbach's } \\
\text { Alpha }\end{array}$ & $\begin{array}{c}\text { Kompozit } \\
\text { Güvenilirlik }\end{array}$ & AVE \\
\hline \multirow[t]{4}{*}{ TUTUM (TUT) } & TUT2 & 0,848 & 0,719 & \multirow[t]{4}{*}{0,882} & \multirow[t]{4}{*}{0,919} & \multirow[t]{4}{*}{0,741} \\
\hline & TUT3 & 0,806 & 0,650 & & & \\
\hline & TUT4 & 0,936 & 0,876 & & & \\
\hline & TUT5 & 0,847 & 0,717 & & & \\
\hline \multirow{3}{*}{$\begin{array}{l}\text { ALGILANAN } \\
\text { DAVRANIŞSAL } \\
\text { KONTROL (DAK) }\end{array}$} & DAK1 & 0,882 & 0,778 & \multirow[t]{3}{*}{0,842} & \multirow[t]{3}{*}{0,904} & \multirow[t]{3}{*}{0,758} \\
\hline & DAK2 & 0,835 & 0,697 & & & \\
\hline & DAK3 & 0,893 & 0,797 & & & \\
\hline \multirow{3}{*}{$\begin{array}{l}\text { SUBJEKTİF } \\
\text { NORMLAR (SUN) }\end{array}$} & SUN1 & 0,832 & 0,692 & \multirow[t]{3}{*}{0,803} & \multirow[t]{3}{*}{0,883} & \multirow[t]{3}{*}{0,715} \\
\hline & SUN2 & 0,901 & 0,812 & & & \\
\hline & SUN3 & 0,801 & 0,642 & & & \\
\hline \multirow{3}{*}{$\begin{array}{l}\text { FIRSATLARI } \\
\text { GÖRME (FIG) }\end{array}$} & FIG3 & 0,849 & 0,721 & \multirow[t]{3}{*}{0,729} & \multirow[t]{3}{*}{0,842} & \multirow[t]{3}{*}{0,641} \\
\hline & FIG4 & 0,735 & 0,540 & & & \\
\hline & FIG7 & 0,813 & 0,661 & & & \\
\hline \multirow{3}{*}{$\begin{array}{l}\text { FINANSAL } \\
\text { DESTEK (FID) }\end{array}$} & FID5 & 0,823 & 0,677 & \multirow[t]{3}{*}{0,793} & \multirow[t]{3}{*}{0,878} & \multirow[t]{3}{*}{0,707} \\
\hline & FID6 & 0,903 & 0,815 & & & \\
\hline & FID7 & 0,792 & 0,627 & & & \\
\hline \multirow{5}{*}{$\begin{array}{l}\text { GİRIŞi̇MCİLİK } \\
\text { NIYYETI (GIN) }\end{array}$} & GIN1 & 0,853 & 0,728 & \multirow[t]{5}{*}{0,922} & \multirow[t]{5}{*}{0,941} & \multirow[t]{5}{*}{0,762} \\
\hline & GIN2 & 0,876 & 0,767 & & & \\
\hline & GIN3 & 0,860 & 0,740 & & & \\
\hline & GIN5 & 0,880 & 0,774 & & & \\
\hline & GIN6 & 0,895 & 0,801 & & & \\
\hline
\end{tabular}

Ayrıksak geçerliliği için Fornell ve Larcker (1981) kuralı uygulanır. Ölçeğin Ayrıksak geçerliliği için Tablo 3'te verilen matristeki çaprazda gösterilen $\sqrt{ } \mathrm{AVE}$ değelerinin satır ve sütundaki diğer değerlerden yüksek olması gerekmektedir. Bu sonuçlarla Ayrıksak geçerliliği de teyit edilmiştir.

Tablo 3. Fornell-Larcker k1stas analizi

\begin{tabular}{lcccccc}
\hline & TUT & GIN & FID & DAK & SUN & FIG \\
\hline TUT & $\mathbf{0 , 8 6 1}$ & & & & & \\
\hline GIN & 0,746 & $\mathbf{0 , 8 7 3}$ & & & & \\
\hline FID & 0,182 & 0,354 & $\mathbf{0 , 8 4 1}$ & & & \\
\hline DAK & 0,435 & 0,524 & 0,242 & $\mathbf{0 , 8 7 0}$ & & \\
\hline SUN & 0,352 & 0,357 & 0,205 & 0,274 & $\mathbf{0 , 8 4 6}$ & \\
\hline FIG & 0,378 & 0,380 & 0,157 & 0,383 & 0,127 & $\mathbf{0 , 8 0 1}$ \\
\hline
\end{tabular}

\subsection{Yapisal Model}

Girişimcilik Niyetindeki (GIN) değişimi, Girişimcilik Davranışına Yönelik Kişisel Tutum (TUT), Algılanan Davranışsal Kontrol (DAK), Sübjektif Norm (SUN), Firsatları görme (FIG) ve Finansal Destek (FIG), $\mathrm{R}^{2}=0,644$ (Uyarlanmış $\left.\mathrm{R}^{2}=0,625\right)$ değeri ile açıklamaktadır. $\mathrm{f}^{2}$ etki büyüklüğü değerleri incelendiğinde de girişimcilik niyeti üzerinde TUT'un $(0,698)$ büyük, FID $(0,085)$ ve DAK'ın $(0,072)$ ise küçük etkiye sahip olduğu görülürken, SUN $(0,007)$ ve FIG'ın $(0,005)$ etkisinin olmadığı belirlenmiştir (Cohen, 1988). Bu sonuçlar yapısal modelin yeterli açıklayıcı güce sahip olduğunu teyit etmiştir.

Modeldeki yolların/ilişkilerin istatistiksel anlamlılığı için Tİstatistiği kullanılmıştır. Girişimcilik Davranışına Yönelik 
Kișisel Tutum (TUT) ile Girișimcilik Niyeti (GIN) arasındaki yol $(\mathrm{t}=7,373 ; \mathrm{p}<0,001)$ anlamlı bulunmuştur. Algılanan Davranışsal Kontrol (DAK) ile Girişimcilik Niyeti (GIN) arasındaki yol $(\mathrm{t}=2,333 ; \mathrm{p}<0,05)$ anlaml bulunmuştur. Sübjektif Norm (SUN) ile Girişimcilik Niyeti (GIN) arasındaki yol $(\mathrm{t}=0,747 ; \mathrm{p}>0,05)$ anlaml bulunmamıștır. Fırsatları görme (FIG) ile Girișimcilik Niyeti (GIN) arasındaki yol $(\mathrm{t}=0,677 ; \mathrm{p}>0,05)$ anlaml bulunmamıştır. Son olarak, Finansal Destek (FID) ile Girişimcilik Niyeti (GIN) arasındaki yol $(\mathrm{t}=2,379 ; \mathrm{p}<0,05)$ anlamlı bulunmuştur. İlgili hipotezler ile T-İstatistiği sonuçları Tablo 4'de özetlenmektedir.

Tablo 4. Hipotezlerin sonuçları

\begin{tabular}{lcccccc}
\hline Hipotez & Std $\beta$ & $\begin{array}{c}\text { Örnek } \\
\text { Ortalamas1 }\end{array}$ & $\begin{array}{c}\text { Standart } \\
\text { Hata }\end{array}$ & $\begin{array}{c}\text { T } \\
\text { İstatistiği }\end{array}$ & $\begin{array}{c}\mathrm{p} \\
\text { Değerleri }\end{array}$ & Sonuç \\
\hline H1: TUT $\rightarrow$ GIN & 0,595 & 0,582 & 0,081 & 7,373 & 0,000 & Desteklendi \\
\hline H2: DAK $\rightarrow$ GIN & 0,189 & 0,194 & 0,081 & 2,333 & 0,020 & Desteklendi \\
\hline H3: SUN $\rightarrow$ GIN & 0,053 & 0,057 & 0,070 & 0,747 & 0,455 & Desteklenmedi \\
\hline H4: FIG $\rightarrow$ GIN & 0,048 & 0,059 & 0,071 & 0,677 & 0,499 & Desteklenmedi \\
\hline H5: FID $\rightarrow$ GIN & 0,182 & 0,184 & 0,077 & 2,379 & 0,018 & Desteklendi \\
\hline
\end{tabular}

Şekil 2 elde edilen bu sonuçlar temelinde yeniden gözden geçirilen yapısal modeli göstermektedir.

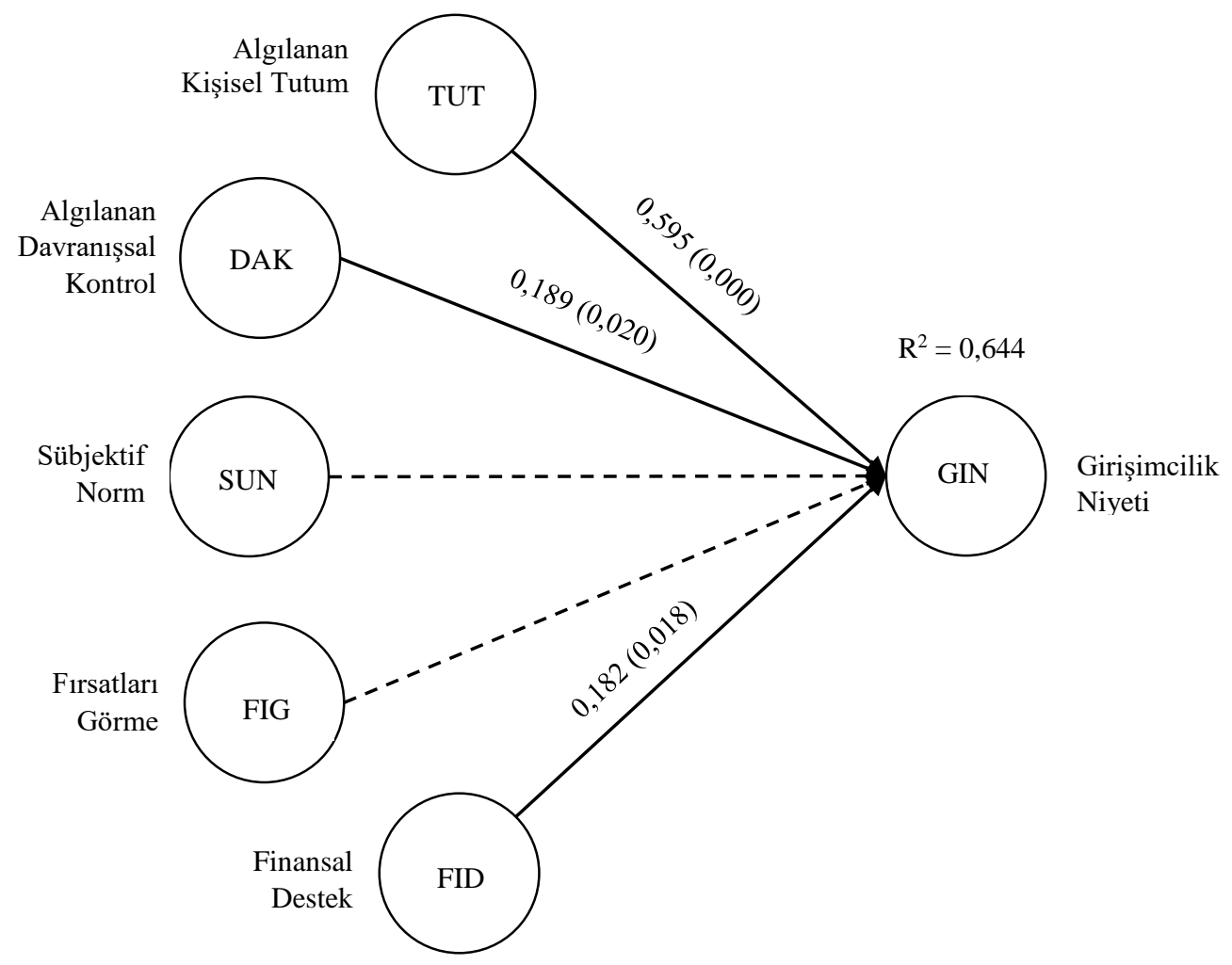

Şekil 2. Yapısal model sonuçları

\section{Sonuç ve Öneriler}

Bu çalışmada Ajzen'in (1991) Planlı Davranış Teorisi temelinde algılanan kişisel tutum, algılanan davranışsal kontrol, sübjektif norm ile firsatları görme ve finansal desteğin girişimcilik niyeti üzerine etkisi incelenmiştir. Ajzen (1991), kişisel tutum, sübjektif norm ve algılanan davranışsal kontrolü girişimcilik niyetinin öncülleri olarak tanımlamaktadır.

Araştırmadan elde edilen sonuçlara göre, girişimciliğe yönelik arzu ve çekim derecesi olan algılanan kişisel tutumun girişimcilik niyetini etkilediği bulunmuştur. Bu sonuç literatür (Kalkan, 2011) ile uyumludur. Bir tür fizibilite algılaması ve bireydeki yeterlilik ölçüsü olan algılanan davranışsal kontrol, bireyin girişimcilik kapasite algısını ifade eder. Çalışmada algılanan davranışsal kontrolün girişimcilik niyetini etkilediği hipotezi desteklenmiştir. Bu sonuç literatür (Yeşilay ve Yavaş, 2017) ile uyumludur. Diğer taraftan, algılanan normatif sosyal baskı düzeyi ve bir davranışı benimseme inancı olarak tanımlanan sübjektif norm girişimcilik niyetinin diğer bir öncülüdür. Sübjektif normun girişimcilik niyetini etkilediğini ifade eden hipotez desteklenmemiştir. $\mathrm{Bu}$ sonucun elde edilmesinde ailelerin ve sosyal çevrenin önemli olduğu düşünülebilir. Buli ve Yesuf'un (2015) yaptığı çalışmada da girişimcilik niyeti için en öngörülebilir iki öncül olarak girişimcilik davranışına yönelik tutum ve algılanan davranışsal kontrol olduğu belirtilmektedir. Benzer sonuçlar Ekici ve 
Turan'ın (2017) yaptığı araștırmada da bulunmuștur. Bu bağlamda elde edilen bu sonuçlar literatür ile uyumludur.

Fırsatları görme biraz da mevcut durumu irdelemeyle alakalıdır. Sürekli gelişen bir pazarda dinamik olmak rakiplerden farklılaşmayı ve ilerlemeyi beraberinde getirebilir. Başarılı girişimciler pazardaki firsatları belirleme ve kullanma becerisine sahiptir (Tumasjan ve Braun, 2012). Kyndt ve Baert'in (2015) çalışmasında olduğu gibi bu çalışmada da firsatları görmenin girişimcilik niyeti üzerinde etkili olmadığ bulunmuştur. Hem bireylerin hem de kurumların SWOT analizi (güçlü yönler - zayıf yönler - firsatlar - tehditler) yapmaları, rekabet stratejilerine odaklanmaları geleceği şekillendirme ve başarı anlamında bir gerekliliktir. Bireylerin henüz gelecekle ilgili bir planlama içerisinde olmamaları bu sonucun elde edilmesinde etkili olmuş olabilir. Mevcut derslerin içeriğinin konuya daha fazla destek verecek şekilde yeniden planlanması pazarı anlamada ve gelişmeleri anlamlandırmada değer ortaya çıkarabilir.

Finansal desteğin girişimcilik niyetinde etkili olduğu bulunmuştur. Bu sonuç Özdemir ve Akın'ın (2018) çalışmalarında elde ettiği bulgular ile uyumludur. Belirtilen çalışmaya göre devlet desteği için devlet tarafından verilen eğitimlerin yeterince etkili olmadığı ancak bu eğitimlere yönelik motivasyonun temel kaynağının verilecek parasal destekler olduğu belirtilmektedir. Günümüzde en kit kaynaklar arasında sayılabilecek etkenlerden bir tanesi de bu finansal destektir. Ancak, gerek küçük orta boy işletmeler gerekse bireysel girişimcilerin erişimde zorluklar yaşadığı teşviklerin alınmasının son yıllardaki ekonomik türbülans ile daha da zorlaştığı görülmektedir. KOSGEB imkânları ile girişimcilere çeşitli destekler sunarken, kaynaklarının sınırlı olması geniş bir girişimci kitlesi için hayal olmanın ötesine geçememektedir.

Elde edilen bu sonuçlar girişimcilik dersini henüz almamış genç üniversite öğrencileri üzerine yapıldığı için oldukça anlamlıdır. Girişimcilik aslında toplumda çocuk yaşlardan itibaren bir kültür haline-getirilebildiğinde ülke kalkınması için olumlu sonuçlar ortaya çıkarabilecek bir kavramdır.

Araştırmacıların üzerinde hemfikir olduğu kanı yeterliliklerin değişmez özellikler olmadığı, deneyim ve eğitim yoluyla geliştirilebilir ve öğrenilebilir olduğudur (Wagener vd., 2010). $\mathrm{Bu}$ da girişimcileri destekleyen bir durumdur. Türkiye yüksek öğretimde her ile en az bir üniversite kurarak önemli bir atılım gerçekleştirmiştir. Hatta daha ileri giderek nüfus yoğunluğu, coğrafi avantaj ya da sosyalleşme gibi diğer değişkenler dikkate alınmadan ilçelere bile üniversite yerleşkeleri kurmuştur. $\mathrm{Bu}$ yapılaşmayı işlevsel hale getirmek için üniversitelerin girişimci bakış açısı yönelimini göz önünde bulundurmaları sağlanmalıdır. Böylece tabana yayılan yükseköğrenimin işlevleri arasında somut çıktılar bağlamında girişimci bireyler yetiştirilmesi de yer alabilir. Bu kültürel bir dönüşüme öncülük edilmesinin önünü açabilir. Çünkü Türkiye potansiyel olarak sahip olduğu coğrafi, kültürel ve ekonomik kaynak üstünlüğünü ve insan kaynağını daha etkin şekilde kullanarak daha zengin bir toplum haline dönüşebilir.

Ülkenin mevcut kültürel kodlarının girişimcilikle ilişkilendirilememesi dünyanın geldiği politik, ekonomik, sosyal ve teknolojik çevrede Türkiye'nin küresel rekabette hak ettiği yere gelemeyeceği gerçeğini ortaya çıkarmaktadır. Girişimcilik ekosisteminin daha fazla geciktirilmeden planlanması ve uygulamaya geçirilmesi bir gerekliliktir. Bunun için kamu önderliğinde kurulacak bir örgüt yapısı ile toplumun bütün paydaşları için bir vizyon belgesi oluşturulabilir. Kitle üretim modeli şeklinde bir yapılanma ile ilkokuldan yükseköğretime kadar geçen eğitim öğretim hayatı yeniden şekillendirilebilir. Burada Milli Eğitim Bakanlığı'nın üzerinde çalıştığı yeni sistem girişimcilik için bir firsat olarak değerlendirilebilir. Yükseköğretim Kurulu'nun bunu tamamlayıcı adımlar atması ilave katkı olabilir. Kültürel dönüşüm için RTÜK'ten medyada konunun teşvik edilmesini sağlayacak şekilde önlem alması istenebilir. Ticaret, Sanayi ya da Kültür gibi ilgili bakanlıklar bu bağlamda dizilerde girişimcilikle ilgili açık veya gizli şekilde olumlu mesajlar verilmesi için yapımcıları teşvik edecek düzenlemeler yapabilir. Girişimciliğin kültürle oluştuğu ve eğitimle de geliştirilebildiği teorik bilgisinden hareketle bütünsel bir bakış açısı ile eğitiminin aileden başlaması için öncelikle ailelerin algılarının bu yönde evirilmesinde yapılacak iletişim çabalarına diğer tüm kamu ve özel sektör girişimlerinin de destek vermesi ile zaman içinde olumlu sonuçların ortaya çıkacağı bir gerçektir.

Araştırma çeşitli kısıtlara sahiptir. Kesitsel bir çalışmadır ve sınırlı sayıdaki öğrencilerle yapılmıştır. Araştırma mevcut durumu incelemek üzere henüz girişimcilik dersi almamış uygulamalı bilimler yüksekokulu ikinci sınıf öğrencilerini kapsamaktadır. Farklı bölge, zaman ve koşullarda, farklı öğrenciler üzerinde yapılacak araştırmalar farklı sonuçlar verebilir. Girişimcilik bağlamında yapılacak boyutsal bir araştırma ile öğrencilerin ilk ve son sınıfları arasındaki gelişimleri takip edilebilir. Benzer şekilde girişimcilik dersi öncesi ve sonrasında yapılacak ölçümler ile girişimcilik farkındalığındaki gelişmeler araştırılabilir.

\section{Kaynakça}

Abou-Warda \& Sherein H. (2015). Entrepreneurial orientation in business schools: A comparative study of higher education systems in Egypt. International Journal of Educational Management, 29 (2), 192-212.

Ajzen, I. (1991). The theory of planned behaviour. Organizational Behaviour and Human Decision Processes, 50 (2), 179-211.

Armstrong, S.J. \& Hird, A. (2009). Cognitive style and entrepreneurial drive of new and mature business ownermanagers. Journal of Business and Psychology, 24 (4), 419-430.

Bulı B.M. \& Yesuf, W.M. (2015). Determinants of entrepreneurial intentions Technical-vocational education and training students in Ethiopia. Education + Training, 57 (8/9), 891-907.

Chaudhary, R. (2017). Demographic factors, personality and entrepreneurial inclination: A study among Indian university students. Education + Training, 59 (2), 171-187.

Cohen, J. (1988). Statistical Power Analysis for the Behavioral Sciences (2e). Hillsdale, NJ: Lawrence Earlbaum Associates. 
Cunningham, J.B. \& Lischeron, J. (1991). Defining entrepreneurship. Journal of Small Business Management, 29 (1), 45-61.

Diaz-Garcia, M.C. \& Jiménez-Moreno, J. (2010). Entrepreneurial intention: the role of gender. International Entrepreneurship Management Journal, 6 (3), 261-283.

Ekici, E. \& Turan, M. (2017). Üniversite Öğrencilerinin Girișimcilik Eğilimi: Planlanmıș Davranışlar Teorisi Ve Girişimcilik Eğitiminin Rolü. Çukurova Üniversitesi Sosyal Bilimler Enstitüsü Dergisi, 26 (1), 201-215.

Elenurm, T. (2012). Entrepreneurial orientations of business students and entrepreneurs. Baltic Journal of Management, 7 (2), 217-231.

Fayolle, A., Liñán F. \& Moriano, J.A. (2014). Beyond entrepreneurial intentions: values and motivations in entrepreneurship. International Entrepreneurship and Management Journal, 10 (4), 679-689.

Fornell, C. \& Larcker, D.F. (1981). Evaluating structural models with unobservables variables and measurement error. Journal of Marketing Research, 18 (1), 39-50.

Gaddam, S. (2007). A conceptual analysis of factors influencing entrepreneurship behavior and actions. ICFAI Journal of Management Research, 6 (11), 46-63.

Gras, D. \& Mendoza-Abarca, K. I. (2014). Risky business? The survival implications of exploiting commercial opportunities by nonprofits. Journal of Business Venturing, 29, 392-404.

Hair, J.F., Hult, G.T.M., Ringle, C.M. \& Sarstedt, M. (2014). A Primer on Partial Least Squares Structural Equation Modeling (PLS-SEM), SAGE Publications.

Hemingway, C. A. (2005). Personal values as a catalyst for corporate social entrepreneurship. Journal of Business Ethics, 60 (3), 233-249.

Henley, A., Contreras, F., Espinosa, J.C. \& Barbosa, D. (2017). Entrepreneurial intentions of Colombian business students: Planned behaviour, leadership skills and social capital. International Journal of Entrepreneurial Behavior \& Research, 23 (6), 1017-1032.

Hulland, J. (1999). Use of partial least squares (PLS) in strategic management research: A review of four recent studies. Strategic Management Journal, 20 (2), 195-204.

Kalkan, A. . (2011). Kişisel Tutum, Öznel Norm Ve Algılanan Davranış Kontrolünün Girişimcilik Niyeti Üzerindeki Etkisi: Üniversite Öğrencileri Üzerine Bir Uygulama. Süleyman Demirel Üniversitesi Sosyal Bilimler Enstitüsü Dergisi, 14, 189-206.

Kerse, G. Babadağ, M. ve Kerse, Y. (2017). Girişimcilik Eğitiminin Girişimcilik Niyetine Etkisi: Girișimsel ÖzYetkinliğin Aracı Rolü. Süleyman Demirel Üniversitesi Sosyal Bilimler Enstitüsü Dergisi, 29, 633-656.

Kirzner, I. (1978). Competition and Entrepreneurship. University of Chicago Press, Chicago, IL. (Aktaran: Elenurm, 2012).

Knight, F.H. (1921). Risk, Uncertainty, and Profit. Riverside Press, Cambridge. (Aktaran: Elenurm, 2012)
KOSGEB

https://www.kosgeb.gov.tr/site/tr/genel/destekler/6312/gir isimcilik-destekleri (Erişim 19.05.2019)

Krueger, N.F. \& Carsrud, A.L. (1993). Entrepreneurial intentions: applying the theory of planned behavior. Entrepreneurship and Regional Development, 5 (1), 315330.

Krueger, N.F. JR, Reilly, M.D. \& Carsrud, A.L. (2000). Competing models of entrepreneurial intentions. Journal of Business Venturing, 15 (5/6), 411-432.

Kyndt, E. \& Baert, H. (2015). Entrepreneurial competencies: Assessment and predictive value for entrepreneurship. Journal of Vocational Behavior, 90, 13-25.

Lee, S.M. \& Peterson, S. (2000). Culture, entrepreneurial orientation, and global competitiveness. Journal of World Business, 35 (4), 401-416.

Lee, S.M., Chang, D. \& Baelim, S. (2005). Impact of entrepreneurship education: a comparative study of the US and Korea. International Entrepreneurship and Management Journal, 1 (1), 27-43.

Linan, F. \& Chen, Y. (2009). Development and cross-cultural application of a specific instrument to measure entrepreneurial intentions. Entrepreneurship: Theory and Practice, 33 (3), 593-617.

Lumpkin, G.T. \& Lichtenstein, B.B. (2005). The role of organizational learning in the opportunity-recognition process. Entrepreneurship Theory \& Practice, 29 (4), 451471.

Maes, J., Leroy, H. \& Sels, L. (2014). Gender differences in entrepreneurial intentions: A TPB multi-group analysis at factor and indicator level. European Management Journal, 32 (5), 784-794.

Marques, C.S., Ferreira, J.J., Gomes, D.N. \& Rodrigues, R.G. (2012). Entrepreneurship education: how psychological, demographic and behavioural factors predict the entrepreneurial intention. Education+Training, 54 (8/9), 657-672.

Mowery, D.C. \& Shane, S. (2002). Introduction to the special issue on university entrepreneurship and technology transfer. Management Science, 48 (1), V-IX.

National Committee of Inquiry into Higher Education (1997). Higher Education in the Learning Society: Report of the National Committee. HMSO, London. (Aktaran: AbouWarda, 2015).

Özdemir, Ş. \& Akın, H.B. (2018). Who Should Provide Education for Entrepreneurship? An Evaluation of Government-Led Entrepreneurship Education Programs in Turkey. Işsletme Araştırmalarl Dergisi / Journal of Business Research-Turk, 10 (2), 89-105.

Schumpeter, J. (1928). The instability of capitalism. Economic Journal, 38, 361-386.

Solesvik, M. (2013). Entrepreneurial motivations and intentions: investigating the role of education major. Education+Training, 55 (3), 253-271. 
Solesvik, M., Westhead, P. \& Matlay, H. (2014). Cultural factors and entrepreneurial intention. Education+Training, $56(8 / 9), 680-696$.

Stamboulis, Y. \& Barlas, A. (2014). Entrepreneurship education impact on student attitudes. The International Journal of Management Education, 12 (3), 365-373.

Toklu, İ.T. \& Ustaahmetoğlu, E. (2016). Tüketicilerin Organik Çaya Yönelik Tutumlarını ve Satın Alma Niyetlerini Etkileyen Faktörler: Bir Alan Araştırması. Uluslararası Yönetim Iktisat ve Issletme Dergisi, 12 (29), 41-61.

Toklu, İ.T. (2018). Üniversite Öğrencilerinin Girişimcilik Niyetini Ne Etkiler? Doğu Karadeniz Bölgesinde Bir Araştırma. BMIJ, 6 (4), 1081-1100.

Toklu, İ.T. (2019). Pazar Yönelimi Girişimcilik Niyetinde Etkili Midir? Üniversiteliler Üzerine Bir Alan Çalışması. C. ̈U. İktisadi ve Ídari Bilimler Dergisi, 20 (1), 335347Ubak 2019, 4. Uluslararası Bilimsel Araştırmalar Kongresi, 14-17 Şubat, Yalova.

Tumasjan, A. \& Braun, R. (2012). In the eye of the beholder: How regulatory focus and self-efficacy interact in influencing opportunity recognition. Journal of Business Venturing, 27 (6), 622-636.

Universities UK (2000). A Forward Look-Highlights of our Corporate Plan, 2001-2004. Universities UK, London. (Aktaran: Abou-Warda, 2015).

Van Auken, H. E. (1999). Obstacles to business launch. Journal of Developmental Entrepreneurship, 4, 175-187.

Volery, T., Mueller, S., \& Von Siemens, B. (2015). Entrepreneur ambidexterity: A study of entrepreneur behaviors and competencies in growth oriented small and medium-sized enterprises. International Small Business Journal, 33, 109-129.

Wagener, S., Gorgievski, M., \& Rijsdijk, S. (2010). Businessman or host? Individual differences between entrepreneurs and small business owners in the hospitality industry. The Service Industries Journal, 30, 1513-1527.

Wennekers, S., Uhlaner, L.M. \& Thurik, R. (2002). Entrepreneurship and its conditions: a macro perspective. International Journal of Entrepreneurship Education, 1 (1), 25-68.

Yeşilay, R.B. \& Yavaş, V. (2017). Öğrencilerin Girişimcilik Niyetinin Planlanmış Davranış Teorisi Çerçevesinde İncelenmesi: Sivil Havacılık Alanında Öğrenim Gören Önlisans Öğrencileri Üzerine Bir Araştırma. Girişimcilik ve İnovasyon Yönetimi Dergisi, 6 (1), 145-172.

\section{EK 1.}

\section{Araştırmada kullanılan değişkenler ve maddeleri}

\section{Davranışa Yönelik Kişisel Tutum}

(1: kesinlikle katılmiyorum, 5: tamamen katıliyorum)

TUT1 Bir girişimci olmak benim için, dezavantajdan daha çok avantaj anlamına gelmektedir*

TUT2 Girişimcilik kariyeri benim için caziptir
TUT3 Fırsat ve kaynaklara sahip olsaydım, bir şirket kurmak isterdim

TUT4 Girişimci olmak benim için büyük bir memnuniyet oluşturur

TUT5 Çeşitli seçenekler arasında, ben daha çok girişimci olmayı tercih ederim

\section{Sübjektif Norm}

(1: kesinlikle katılmıyorum, 5: tamamen katılıyorum)

SUN1 Bir girişimci olsa idim, yakın ailemin buna tepkisi olumlu olurdu

SUN2 Bir girişimci olsa idim, yakın arkadaşlarının buna tepkisi olumlu olurdu

SUN3 Bir girişimci olsa idim, benim için önemli olan insanların buna tepkisi olumlu olurdu

\section{Algılanan Davranışal Kontrol}

(1: kesinlikle katılmıyorum, 5: tamamen katıliyorum)

DAK1 Bir iş (işletme) kurmak ve çalışmaya devam etmek benim için kolay olacaktır

DAK2 Yaşayabilir bir iş kurmaya hazır hissediyorum.

DAK3 Yeni bir işletmenin yaratılış (ortaya çıkış) sürecini kontrol (idare) edebilirim

DAK4 Bir iş kurmak için gerekli pratik (uygulanabilir) ayrintılart biliyorum*

\section{DAK5 Girişimci bir projenin nasıl geliştirileceğini bilirim*}

DAK6 Ĕger bir iş kurmak için girişimde bulunmuş olsaydım, başarlya ulaşma şansım yüksek olurdu*

\section{Fırsatları Görmek}

(1: kesinlikle katılmıyorum, 5: tamamen katılıyorum)

FIG1 Pazarın ihtiyaç duyduğu şeylere özgün bir cevap veriyorum*

\section{FIG2 Sektörümde henüz neyin satılmadığını biliyorum*}

FIG3 Pazara yeni ürün veya hizmet sunumu için orijinal fikirlerim var

FIG4 (Gelecekteki) müşterilerimin ne zaman yeni ürün veya hizmetler istediğini biliyorum

FIG5 Faaliyet gösterdiğim sektörde ortaya çıkacak yeni gelişmeler hakkında ileriyi düşünebilirim*

FIG6 Ortamımda hangi ihtiyaçların ve gereksinimlerin olduğunu biliyorum*

FIG7 Fırsatlara yaratıcı bir şekilde cevap verebilirim

\section{Finansal Destek}

(1: hiç önemli değil 7: çok önemli)

FID1 Yeni girişimcilere KOSGEB'in Max. 2000 TL hibe kuruluş desteği benim için caziptir*

FID2 Yeni girişimcilere KOSGEB'in Max. 18000 TL hibe Kuruluş Dönemi Makine, Teçhizat, Yazılım ve Ofis Donanım Desteği benim için caziptir*

FID3 Yeni girişimcilere KOSGEB'in Max. 30000 TL hibe İsletme Giderleri Desteği benim için caziptir* 
FID4 Yeni girişimcilere KOSGEB'in Max. 100000 TL faizsiz geri ödemeli Sabit Yatırım Desteği benim için caziptir*

FID5 Yeni girişimcilere KOSGEB’in Eğitim desteği benim için caziptir

FID6 Yeni girişimcilere KOSGEB'in Düşük faizli işletme kredisi benim için caziptir

FID7 Kadın girişimcilere KOSGEB'in 30000 TL ye kadar faizsiz kredi benim için caziptir

\section{Girişimcilik Niyeti}

(1: kesinlikle katılmiyorum, 5: tamamen katılıyorum)
GIN1 Girişimci olmak için gerekli her şeyi yapmaya hazırım GIN2 Profesyonel hedefim bir girişimci olmaktır

GIN3 Kendi işimi kurmak ve çalıştırmak için her türlü çabay1 göstereceğim

GIN4 Gelecekte bir işletme yaratmaya (kurup geliştirmeye) kararlıyım*

GIN5 Çok ciddi bir şekilde bir iş kurmayı kafamdan geçirdim GIN6 Bir gün bir iş kurmak için kararlıyım

*Düşük faktör yükü nedeniyle analizden çıkarılmıştır 